J. Asiat. Soc. Bangladesh, Sci. 38(1): 99-109, June 2012

\title{
ECOLOGY AND BREEDING BIOLOGY OF THE POND HERON, ARDEOLA GRAYII (SYKES, 1832) AND ITS CONSERVATION ASPECTS
}

\author{
M. FIROJ JAMAN ${ }^{1}$, MD. NAZMUL HOQUE ${ }^{1}$, NOOR JAHAN SARKER ${ }^{1}$ \\ AND MD. SAIDUR RAHMAN ${ }^{1}$ \\ ${ }^{I}$ Department of Zoology, University of Dhaka, Dhaka 1000, Bangladesh
}

\begin{abstract}
Studies on ecology and breeding biology of the pond heron, Ardeola grayii was conducted from January to June, 2010 in Kalairpur Assim Union, Fulbaria under Mymensingh district. The breeding season of this bird ranged from February to June. The peak period for nesting was March. The pond heron choose the nesting site surrounding the human settlements near the pond and other water bodies. This species took 7 to 14 days to complete nest with an average of 10.8 days. The height of nest varied from $5.2 \mathrm{~m}$ to $10.9 \mathrm{~m}$ with an average of $7.82 \mathrm{~m}$. The main nesting trees were bamboo (Bambusa longispiculata) and mango (Mangifera indica). Nesting materials were chiefly small sticks of mango, tamarind (Tamarindus indica), bel (Aegle marmelos) and leaves of bamboos. The clutch size varied from 3 to 4 eggs with an average of 3.7 eggs. The incubation period varied from 19 to 23 days with an average of 20.73 days. The hatching success was $90 \%$ in relation to the number of eggs laid. The fledging period of young varied from 25 to 29 days with an average of 26.73 days. Young individuals left the nest after 3 to 4 weeks. Results of this study indicate that the pond heron can breed successfully for their survival if indigenous plants trees are available to build their nest. So Government should make immediately an integrated conservation plan to protect this bird with the co-operation of national and international organizations.
\end{abstract}

Key words: Ecology, breeding biology, pond heron, conservation aspect

\section{Introduction}

The pond heron, Ardeola grayii is locally known as Kani bok/ kana bok / korchey bok and is common resident bird of Bangladesh. It is usually found to forage alone or in small, loose parties and occurs in all water bodies across the country (Ali and Ripley 1983). It is colonial nesting species, frequently found on the fresh water marshes, ditches, canals, riverbanks, paddy fields, jheels, tidal flats and other such natural wetlands. The pond heron chiefly feeds on animal matter, mainly on fishes, crustaceans, insects, amphibians and some vegetables on the ground (Ali and Ripley 1983). This heron species is an important biological component to maintain the food chain, ecosystem and can help to control the insect in the agricultural fields.

Some information of breeding biology of the pond heron, Ardeola grayii and other species of birds are available in the literatures and research papers (Baker 1922, Fletcher

\footnotetext{
${ }^{1}$ Corresponding author : Email: mfjaman@yahoo.com
} 
and Inglis 1936, Smythies 1953, Whistler 1963, Brown 1964, Ali and Ripley 1968, 1972, 1983, Henry 1971, Ali 1977, Husain 1979, Zacharias and Gaston 1982, Sarker 1987, Khan 1988, Ray 1992, Jaman et al. 1997, Jaman and Sahreen 2004). However, to the best of our knowledge, no detailed research work on the breeding ecology of this bird has been reported. Therefore, we conducted a detail research on the ecology and breeding biology of the pond heron. This study may help in the conservation of this bird species.

\section{Materials and Methods}

The study was carried out from January 2010 to June 2010. Information in detail on the breeding biology of 10 nests was collected. The study area was visited from two to four times in each month in order to collect sufficient data. The methods adopted were (i) selection of nesting trees and (ii) counting of nests and birds. Roosting and nesting trees of the pond heron were identified and listed. Vegetation and fauna of the study area were also recorded. Interview was conducted to local people to gather more information about the studied species. Density of nest was calculated per $12 \mathrm{~km}^{2}$ area. Feeding ground was also surveyed to observe the feeding behaviour. For closer observations in mating, nest building, incubation, brooding, nestling and fledging of birds a portable hide and a pair of binoculars were used. The activities of the pond heron were also observed with the help of a pair of binocular. Digital camera was used to take photographs of various activities of the birds. For weighing and measuring the nests, eggs, nestling and young ones, an electric balance, spring balance, a wooden scale, a steel tape, a plastic tape and slide caliper were used. The eggs were marked as $1,2,3,4,5$, etc. according to laying of eggs to determine the incubation period and hatching intervals. Measuring and weighing of eggs were done once in a week and records were kept in tabular form with dates. Any loss of nests, eggs, and nestling and factors affecting the damage of eggs and nestlings were also noted. Fledging period, breeding success and activities of young before and after left the nest were also recorded. Breeding season and inter action with other birds at that time were also observed and noted. Plastic bottle and formalin were used to keep and preserve the dead nestlings, eggs and food materials.

Study Area : The study area is situated under the Assim Union, Fulbaria Upazila in the district of Mymensingh and about $110 \mathrm{~km}$ north of Dhaka. It is predominantly agricultural landscape and the colony is on the backyard trees in the middle of rural settlement. The study area was divided into two 'paras' known as Uttarpara and Dokhinpara under the village Kalairpur. It is about $20 \mathrm{~km}$ far from Fulbaria Upazila. The total study area is approximately two acres. There are four ponds in Shakhidarpara and two ponds in Dakshinapara which are fulfilled by water in the rainy season. Water of the ponds dries up in winter. The approximate area of individual pond of Shakhidarpara is 9 decimal, 15 decimal, 8 decimal and 5 decimal and the approximate area of individual pond of Dakshinpara is 7 decimal and 3 decimal. 
The study area supported a homestead forest including bushes, bamboos, grasses and several other tall and medium sized trees making good covers and shelters for the wildlife. During the study period the average temperature was $29^{\circ} \mathrm{C}$, average humidity $79 \%$ and average rainfall was $298 \mathrm{~cm}$. The dominant vegetations were Aphanamixis polystachya, Cedrella toona, Bambusa longispiculata, B. vulgaris, Trichosanthes bracteata, Derris indica, Samanea saman, Albizia procera, A. richardiana Cassia fistula, Bombyx ceiba, Ficus hispida, F. lacor, Artocarpus heterophylus, Pinus longifolia, Eucalyptus citriodora, Syzygium cumini, Mollolus philippense, Croton tiglium, Miliusa velutina, Solanum torvum, Mangifera indica, Anona squamosa, Polyalthia longifolia, Phoenix sylvestris, Delonix regia, Aegle marmelos and Musa paradisiaca.

\section{Results and Discussion}

Breeding season: Breeding season of the pond heron, means the time of a year during which the animals form pair, mate, build nest, lay eggs and rear the nestling and young. The breeding activities of the pond heron started from February and continued up to June. No breeding activities were found during the rest of the year. The peak nesting record was found in March when the average temperature was about $29^{\circ} \mathrm{C}$, humidity $79 \%$ and rainfall $298 \mathrm{~cm}$.

Baker (1922) mentioned that the breeding season of the pond herons started from December to March in Southern India and June to August in Northern India and Myanmar. Ali (1977) stated that the breeding season in North India was between April and September, December to February in the South.

Pair formation: Pair formation is the first step of breeding biology (Welty 1975). Pairing of the pond herons occurred between February and March. Most of the pairing takes place in February. In this time they like to stay close together all the time. But in the non breeding season they prefer to stay separately. Information was scanty about the pair formation of the pond herons. Sexes were not recognized by earlier authors although some authors mentioned that both sexes were alike.

Sex recognition: Both males and females were looked alike except in the breeding season. The head and neck became yellowish brown in the breeding season. The back became deep maroon with long feathers over the tail. The plumages became longer and white. The tarsal region became reddish in colour. The rest of the body became white. The male pond heron was found to be bigger than the female.

Nest site selection: In the present study the male and the female selected the nesting site. The pond heron choose the nesting site surrounding the human settlements near the pond and other water bodies forfinding food easily. They preferred the top branches of the trees. Generally tree-forks were the favorite sites for nest. This bird builds their nest with other birds like night herons, egret or other storks, etc and form a nesting colony. Nesting trees 
were - bamboo and mango. Whistler (1963) stated that the pond herons preferred to build nests in trees, usually at a good height from the ground. Henry (1971) mentioned that the pond herons preferred to build their nest at varying heights mostly under the tree canopy. Ali and Ripley (1968) mentioned that the nest site was placed in the same sort of sites as used for day time roosts. Ali (1977) found the nesting sites of the pond herons in colonies in canopy of large trees or screw pine brakes and near the water bodies. Ali (1977) stated that the pond herons build their nests in upper canopy of bamboo thickets, bushes and trees.

Nest: The nest was generally a large platform of petioles of leaves and sticks without lining. The shape of the nest might be circular or round or of any other shape suiting the shape of the branch on which the nest was lodged. But its inner side always remained characteristically cup shaped by elevating sides and lowering middle of the nest where the eggs were placed. In the study we found all nests were similar in size and shape.

Birds make their nests mainly to protect themselves, their eggs and particularly their developing young from predatory animals and from adverse weather during the breeding season (Welty 1975).

Nesting trees: In total 150 nests were counted in the colony. Among them, 100 nests were recorded at the village side and 50 nests in the other side. The nesting trees were mainly bamboo, mango, krishnachura and bahera, etc.

Nesting materials: The nest was generally a large platform of twigs and sticks with a core depression in the centre. The pond heron mainly used small sticks of bamboo as nest materials. Besides this they commonly found to use leaves and branches of Tetul (Tamarindus indica), Koroi (Albizia procera), mango, pakur (Ficus relgiosa) and bel (Aegle marmelos).

Collection of nestling materials: The pond heron collected nesting materials from the neighboring trees. The collection of nest material was rapid in the morning and gradually declined towards noon. In the rainy day the collection of nest material was subsided. They picked up nesting materials and quickly carried by beak to the nesting tree and untiringly to build their nest. Only male partner took part in the collection of nesting material and the female stayed in the nest and took part in nest building.

Nest building: Like black drongo (Jaman et al. 1997) both the sexes of the pond heron shared and worked hard in building their nest but the female pond heron was more active than the male. In the earlier part of construction the nest materials were arranged in a criss - cross fashion, resulting a circular platform. When the platform was three to four sticks, the additional sticks were set on it tangentially and converted it into a shallow cup. 
The outer cup was done by both the male and the female though the female did the final construction of the inner cup with its breast, wings, bill and legs. The cups of all the nests were without lining.

Time required for nest building: The pond heron took 7 to 14 days to build the nest (average: 10.8 days, $\mathrm{N}=10$ nests) (Fig. 1). They took comparatively more time in nest building at the starting of the breeding season than late of the breeding season. The minimum height of ten nests from the ground was $5.2 \mathrm{~m}$ and the maximum was $10.9 \mathrm{~m}$ (average: $7.82 \mathrm{~m}$ ).

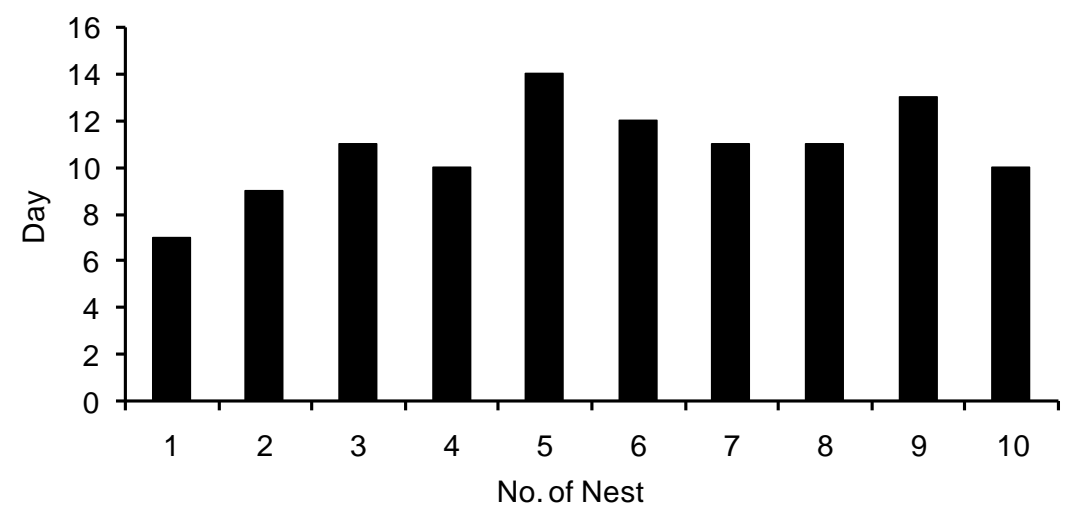

Fig. 1. Total time (days) required for nest building height of the nests.

Measurement of nests: The length of the nests varied from 31.5 to $36 \mathrm{~cm}$ (average: 33.58 $\mathrm{cm}, \mathrm{N}=5$ ). The breadth of the nests varied from 24 to $28 \mathrm{~cm}$ (average: $7.94 \mathrm{~cm}$ ). The depth of the nests cup was 2.4 to $3.5 \mathrm{~cm}$ (average: $2.82 \mathrm{~cm}$ ). The weight varied from 175 to $320 \mathrm{~g}$ (average weight: $247 \mathrm{~g}$ ).

Mating: Mating is the vital fact for breeding biology. For mating they need a quiet environment. In the present study, the mating of the pond heron was observed in the morning and late afternoon. Mating took place on the branches of the trees, or on the ground and even in the nests, sometimes on the ground near the water body and even when the female was sitting on the nest. Before mating the male and the female sat closely together. At that moment the male scratched the female's forehead for several times. Suddenly the male rode over the female's back by constantly fluttering his wings and tried to mate with her. The male bird bent his tail along the left or right side of the female's tail and brought their cloaca close together. Mating took place in this fashion. Generally mating lasted for 20 to 30 seconds. 
Egg Laying: During the present study first egg laying was observed in late March and it was continued until April. The gap between the completions of laying of eggs varied from 1 to 2 days.

Clutch size and time of egg laying: The clutch size is the complete set of eggs laid by one female which are brooded simultaneously (Thomson 1964). The pond heron has one clutch size in a year in nature. Its clutch size varied from 2 to 4 with an average of 3 eggs. Most of the eggs were laid at late night or early in the morning. Usually this species laid one egg a day until the clutch was completed. The gap between egg laying varied from 1 to 2 days. It was found that two eggs were not laid in the same day. The shapes of the eggs were broad, longish oval and somewhat pointed towards the smaller end. The colour of egg was usually pale greenish blue without any marking as was mentioned by Ali and Ripley (1972). The egg color changed into dark before hatching.

Measurements and weight of eggs: In total 30 eggs were measured. The maximum length was $42 \mathrm{~mm}$ and the minimum length was $34 \mathrm{~mm}$ and the maximum breadth was $37 \mathrm{~mm}$ and minimum breadth was $29 \mathrm{~mm}$ (average length/breadth: 39.52/32.56 mm). The average weight of eggs was $20.05 \mathrm{~g}$ (Table 1). The maximum and the minimum weight were $23.5 \mathrm{~g}$ and $17 \mathrm{~g}$, respectively. It was found that the weight of the eggs gradually decreased with the time of incubation. The decreasing rate was very high for infertile eggs.

Table 1. Estimated measurement of eggs.

\begin{tabular}{|c|c|c|c|c|c|c|c|c|c|}
\hline \multirow{2}{*}{$\begin{array}{l}\text { Sl. No. } \\
\text { of nest }\end{array}$} & \multirow{2}{*}{$\begin{array}{c}\text { Clutch } \\
\text { size }\end{array}$} & \multicolumn{4}{|c|}{ Weight of eggs (g) } & \multirow{2}{*}{$\begin{array}{l}\text { Mean } \\
\text { weight } \\
\text { (g) }\end{array}$} & \multirow{2}{*}{$\begin{array}{c}\begin{array}{c}\text { Average } \\
\text { weight } \\
\text { (g) }\end{array} \\
\end{array}$} & \multirow{2}{*}{$\begin{array}{l}\text { Maximum } \\
\text { weight } \\
\text { (g) }\end{array}$} & \multirow{2}{*}{$\begin{array}{c}\text { Minimum } \\
\text { weight } \\
\text { (g) }\end{array}$} \\
\hline & & 1st & 2nd & 3rd & 4th & & & & \\
\hline 1 & 3 & 21 & 20.3 & 22 & - & 21.5 & & & \\
\hline 2 & 3 & 17 & 23.5 & 22 & - & 20.83 & & & \\
\hline 3 & 2 & 20 & 22 & - & - & 21 & & & \\
\hline 4 & 3 & 18 & 22 & 20 & - & 20 & & & \\
\hline 5 & 4 & 21 & 22 & 19 & 17 & 19.75 & 20.05 & 23.5 & 17 \\
\hline 6 & 3 & 19 & 18 & 20 & - & 19 & & & \\
\hline 7 & 3 & 21.5 & 22 & 18.5 & 30 & 20.67 & & & \\
\hline 8 & 2 & 19 & 17 & - & - & 18 & & & \\
\hline 9 & 4 & 19 & 20.5 & 22 & 21.5 & 20.5 & & & \\
\hline 10 & 3 & 22 & 18.5 & 18.5 & - & 19.67 & & & \\
\hline
\end{tabular}

Incubation: Incubation is the process by which the heat necessary for embryonic development is applied to an egg after it has been laid (Thomson 1964). In case of the pond heron, incubation started as soon as the first egg was laid and continued up to the hatching. It was found that the incubation was not continuous in the day time and the eggs remained uncovered for sometimes. The female pond heron played a vital role for incubation. She incubated the eggs continuously at night and the male shared during the 
day time. When the female went out in search of food, the male entered the nest and sat on the eggs until the female came back. The female spent $97.25 \%$ time and the male spent $2.75 \%$ time in incubation. Ali and Ripley (1968) mentioned that both sexes took part in incubation. During incubation, the incubating bird changed their face at several directions and moved after a few minutes interval. Sometimes they transferred the position of eggs with their bills.

The percentages of incubating time in $5^{\text {th }}, 10^{\text {th }}, 15^{\text {th }}$, and $20^{\text {th }}$ day were $87.77 \%, 85 \%$, $82.22 \%$ and $79.16 \%$, respectively (Table 2 ). In this study, the incubation period was considered from laying of first egg to its hatching (Welty 1975). The incubation period varied from 19 to 23 days with an average of $21.01(\mathrm{SD}=0.86)$ days.

Table 2. Duration of incubating time in the day time.

\begin{tabular}{|c|c|c|c|c|c|c|c|c|c|c|c|c|c|c|c|}
\hline \multirow{2}{*}{$\begin{array}{l}\text { Sl. } \\
\text { No. } \\
\text { of } \\
\text { Nest }\end{array}$} & \multirow{2}{*}{ Day } & \multicolumn{12}{|c|}{ Incubating time (Min.) } & \multirow{2}{*}{$\begin{array}{l}\text { Incubation } \\
\text { time (Min.) }\end{array}$} & \multirow{2}{*}{$\begin{array}{l}\text { Percentage } \\
\text { of time }(\%)\end{array}$} \\
\hline & & 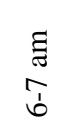 & $\begin{array}{l}\Xi \\
\text { ే } \\
\infty \\
i \\
\sim\end{array}$ & $\begin{array}{l}\text { E } \\
\text { aे } \\
\infty\end{array}$ & $\begin{array}{l}\text { ज्ञ } \\
0 \\
\frac{1}{\alpha}\end{array}$ & $\frac{\Xi}{\Xi}$ & 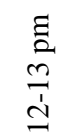 & $\begin{array}{l}\Xi \\
\tilde{z} \\
\dot{J} \\
\dot{\Xi}\end{array}$ & $\begin{array}{l}E \\
\vdots \\
\frac{1}{2} \\
\dot{J}\end{array}$ & 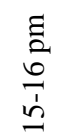 & $\begin{array}{c}\tilde{E} \\
\frac{1}{b} \\
\underline{b}\end{array}$ & \begin{tabular}{l}
$\Xi$ \\
$\vdots$ \\
$\infty$ \\
\multirow{2}{1}{}
\end{tabular} & $\begin{array}{l}\Xi \\
\vdots \\
a \\
\infty \\
\infty\end{array}$ & & \\
\hline 1 & $5^{\text {th }}$ & 53 & 57 & 49 & 55 & 51 & 58 & 50 & 48 & 54 & 56 & 52 & 49 & 632 & $87.77 \%$ \\
\hline 2 & $10^{\text {th }}$ & 52 & 56 & 53 & 47 & 55 & 50 & 51 & 58 & 50 & 45 & 46 & 49 & 612 & $85.00 \%$ \\
\hline 3 & $15^{\text {th }}$ & 44 & 55 & 51 & 45 & 54 & 52 & 48 & 51 & 42 & 47 & 50 & 53 & 592 & $82.22 \%$ \\
\hline 4 & $20^{\text {th }}$ & 40 & 47 & 52 & 50 & 49 & 52 & 53 & 50 & 42 & 43 & 44 & 48 & 570 & $79.16 \%$ \\
\hline
\end{tabular}

Hatching: Out of 30 eggs, 27 hatched and the remaining 3 (10\%) were lost due to various causes. The percentage of hatching success was $90 \%$ in relation to eggs laying. Out of 30 eggs, 2 (2.41\%) were hatched in April and 25 (92.59\%) in May. Generally the eggs hatched in order in which they were laid. The minimum gap between hatching of eggs was 1 day and the maximum gap was 3 days.

Post hatching: The newly hatched young was naked. The eyes were closed. They were too weak and completely dependent on their parents. The featherless body was blackish in colour and the abdomen was almost transparent. The mouth cavity of hatchling was reddish in colour.

Out of 10 nests studied, six nests contained three broods and four nests contained two broods (Fig. 2A). The average brood size was 2.7. The parents covered the young for protection from the sun, rain, and predator as well as to incubate the rest of the eggs. The role of the male and the female in brooding was same as in incubation. The frequency decreased with the increase of the nestling's age. The brooding period varied from 19.8 to 21.3 days (Fig. 2B). 

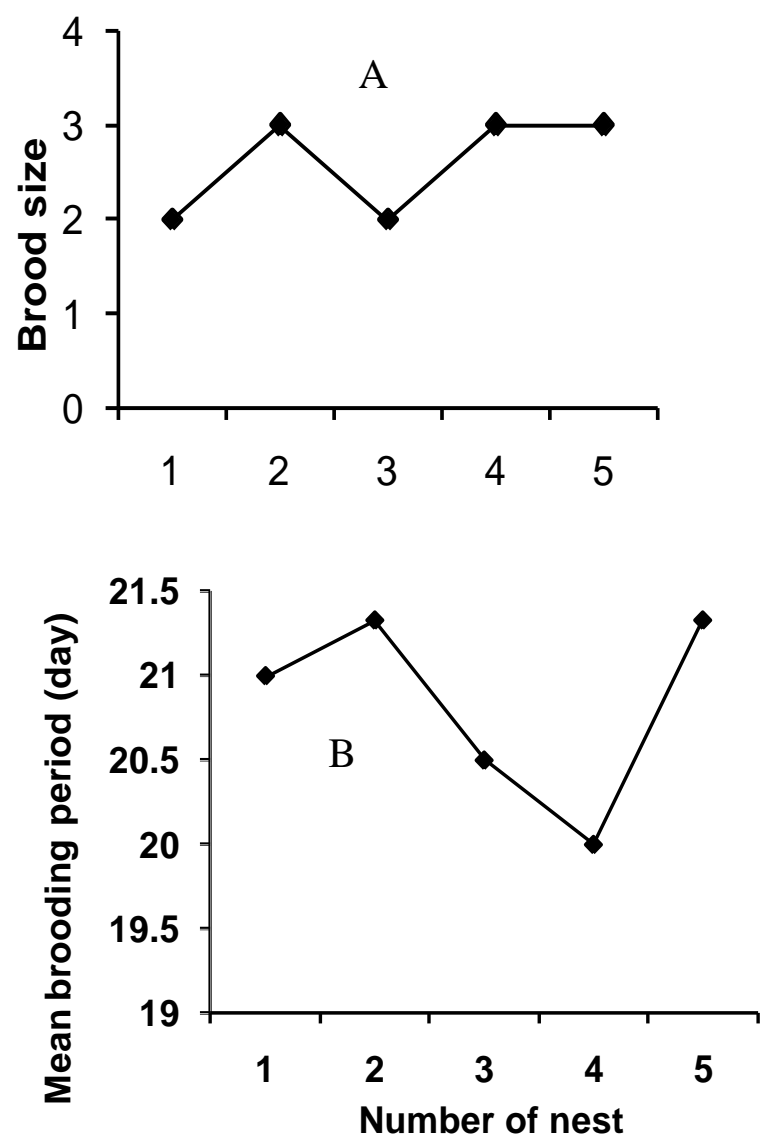

Fig. 2. A. Brood size and B. brooding periods of the pond heron.

Feeding of nestlings: The nestling did not take food for the first 24 to 36 hours. Afterwards, parents collected food and fed the nestlings regularly. When the parents entered into the nest, the nestling made characteristic food beginning noise and opened their mouth cavity widely, pointing towards the parents by stretching the neck as much as possible, and then the parents fed the nestlings by the process of regurgitation. After collection of food the pond herons used to sit on the branch of tree nearby the nest and then entered into the nest for feeding. Sometimes the male transferred some food directly to the mouth of the female for feeding the nestlings. The frequency of feeding was not continuous in whole day. It was the highest in morning and afternoon and at noon. The frequency of feeding visits to the nestlings in a day was found to vary from 8 to 11 times (Fig. 3). 


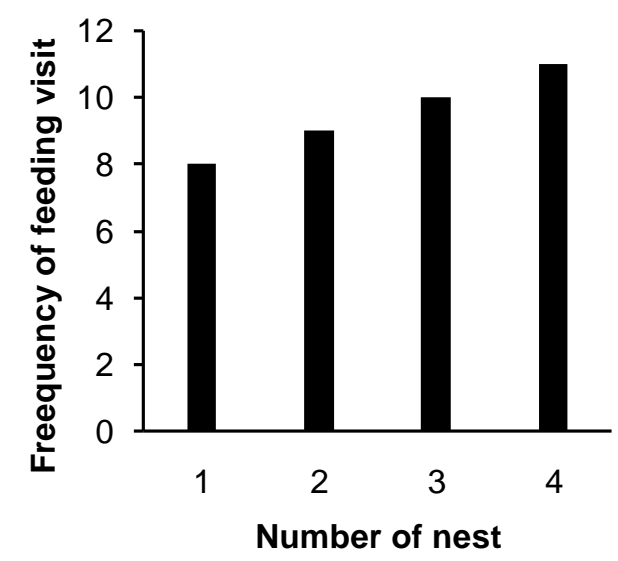

Fig. 3. Different feeding time in the day.

Growth and development of nestlings: After hatching the nestling began to grow and increased in weight gradually. But the rate of increase was not equal in all days of nestling life. The daily weight of nestlings increased continuously up to the age of two weeks (Fig. 4). Afterwards the weight decreased to some extent before leaving the nest. Decrease of weight was due to the factors like human interferences, starvation, natural calamities, etc. The mean weight of newly hatched nestlings was $16 \mathrm{~g}(\mathrm{~N}=12)$. The maximum growth rate of nestling in weight was $228 \mathrm{~g}$ at the $15^{\text {th }}$ day after hatching (Fig. 4). The time required for opening of the eyes was 3 to 5 days and the average time was 3.9 days. The opening was first marked by a very small aperture on the bare skin over both the eyes.

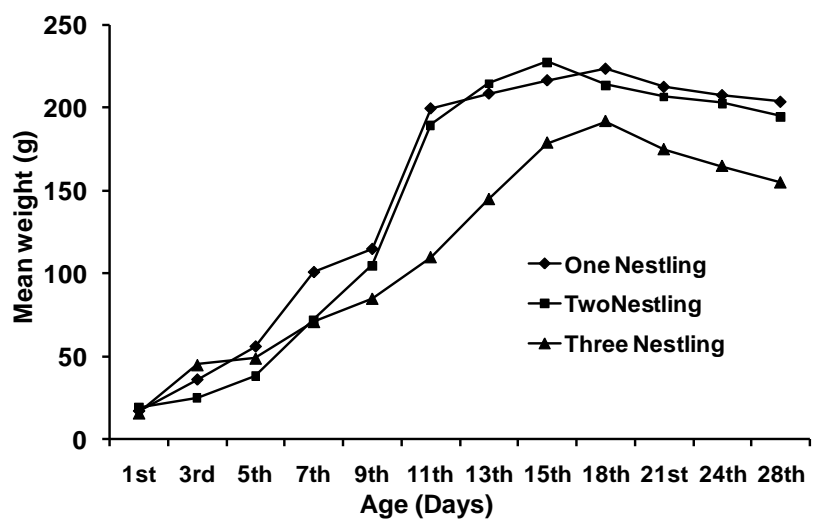

Fig. 4. Average growth curve of broods having one nestling, two nestlings and three nestlings.

Loss of nestlings and nest sanitation: The pond heron was very careful about the sanitation of their nest. The broken shells were removed by the parents after hatching. Both the male and the female shared in nest sanitation. None nestling was destroyed. 
Fledging period: In the study period, the fledging period of the young varied from 25 to 29 days on an average 26.73 days. Out of 27 nestlings, 27 (100\%) fledged successfully. The fledging success was $100 \%$ in relation to hatching and $90 \%$ in relation to egg laying.

Breeding success: The breeding success in relation to the number of eggs laid was calculated to be $90 \%$.

Dispersal: After the successful fledging the young remained in their nest from 2 to 3 weeks. They visited the feeding ground with their parents or went alone to forage and returned to the nest. They finally left the nest and nesting tree after 4 weeks.

Threats and conservation aspects: Although the pond heron is not listed under the threatened species in Bangladesh but their population has been decreasing day by day due to human interferences. The pond herons are colonial breeder. They mainly build their breeding colony near human settlement in rural areas where human disturbances are low. But unfortunately the human activities are the main threat, such as cutting of roosting and nesting trees, destroying the nest and egg, catching young animals, illegal hunting as game bird and industrialization. We should take awareness program for the local people, so that they can stop illegal catching of birds and their nestlings for meat. We should not destroy the breeding environment of the pond heron where they choose for nesting colony. Wildlife preservation Act 1973 should be implemented by the Government authority to protect this important piscivore bird.

\section{References}

Ali, S. 1977. The Handbook of Indian birds (10 ${ }^{\text {th }}$ edition). Bombay Nat. Hist. Soc. Bombay, India. $175 \mathrm{pp}$.

Ali, S. and Ripley, S. D. 1968. Handbook of the birds of India and Pakistan. Vol. 1. Bombay : Oxford University press. $382 \mathrm{pp}$.

Ali, S. and S. D. Ripley. 1972. Handbook of the birds of India and Pakistan. Vol. 5: Bombay : Oxford University press. 278 pp.

Ali, S. and Ripley, S. D. 1983. A pictorial guide to the birds of Indian Sub-continent. Bombay Nat. Hist. Soc. Bombay, India. 177 pp.

Baker, E. C. S. 1922. The Fauna of British India. $2^{\text {nd }}$ ed. Birds. Vol. 1. Taylor and Francis, London. $561 \mathrm{pp}$.

Brown, S. L. 1964. The evaluation of diversity in avian territorial systems. Wilson Bull. 76: $160-$ 164. $201 \mathrm{pp}$.

Fletcher, T. B. and C. M. Inglis. 1936. Birds of an Indian Garden. $2^{\text {nd }}$ Ed. Thacker, Spink and Co. Ltd. Calcutta. $561 \mathrm{pp}$.

Henry, G. M. 1971. A guide to the birds of Ceylon. Oxford University. Press, London, Bombay, New york. 457 pp.

Husain, K. Z. 1979. Birds of Bangladesh. Eden Press, Dhaka, Bangladesh. 84 pp.

Jaman, M. F. and N. Sahreen, 2004. Ecology and breeding Biology of Chestnut - tailed starling, Sturnus malabaricus (Gmelin, 1789). Ecoprint 11(1): 27 - 34. 
Jaman, M. F., S. U. Sarker, and N. J. Sarker, 1997. Breeding Biology of the Black drongo, Dicrurus adsimilis albirictus (Hodgson) in Bangladesh. Dhaka Univ. J. Biol. Sci. 6(2): $185-194$.

Khan, A. R. 1988. Wildlife of Bangladesh. Vol. 11. Bangla Academy, Dhaka, Bangladesh. 173 pp.

Ray, P. C. 1992. Breeding birds of Ramna Park and Suhrawardy Uddayan. M.Sc. thesis (Unpublished), Department of Zoology, University of Dhaka. 96 pp.

Sarker, S. U., 1987. Breeding records of some birds of Bangladesh. Tiger paper 14(1): 12 - 17.

Smythies, B. E. 1953. The birds of Burma. $2^{\text {nd }}$ edition.. Oliver and Boyd: Edinburg, London. 668 pp.

Thomson, A. L. 1964. "Brooding” in a new dictionary of birds. Thomas Nelson and Sons Ltd., London. 928 pp.

Welty, J. C. 1975. The life of Birds. WH Sunders Co. Filadelphia. 754 pp.

Whistler, H. 1963. Popular Handbook of Indian Birds $4^{\text {th }}$ ed. Oliver and Boyd: Edinburgh, London. 560 pp.

Zacharias, V. J. and A. J. Gaston, 1982. Breeding season of birds at Calcutta, South-west India, Ibis 125: $407-412$.

(Received revised manuscript on 28 June 2012) 